\title{
Analysis of Defects in Financial Accounting Management of Construction Enterprises and Corresponding Strategies
}

\author{
Linfang Hou ${ }^{*}$
}

School of Economics and Management, Zhoukou Normal University, Zhoukou, 466001, Henan, China

\begin{abstract}
Knowing the defects in financial accounting management and putting forward corresponding strategies are helpful to improve the level of financial accounting management of enterprises. This paper discusses the defects in financial accounting management of construction enterprises, establishes financial risk prevention system, and explores corresponding strategies. It is shown that the establishment of financial risk prevention system and implementation of corresponding strategies are helpful to reduce financial risks, improve the level of financial accounting management, ensure normal operations of enterprises, create good internal environment for business development, and increase the market competitiveness of enterprises.
\end{abstract}

Keywords: Construction enterprise, defect, financial accounting management, strategy.

\section{INTRODUCTION}

Financial accounting management is a kind of comprehensive activity with strong specialization. It penetrates into all links of business management and plays an important role [1-4]. In contrast with other industries, the construction industry features huge investment, long payback period and high risks. Therefore, financial accounting management of construction enterprises has greater importance [5-7]. For the construction enterprises, to strengthen financial accounting management helps further optimize allocation of enterprise resources, make strategical decisions, implement development plans, achieve development goals, improve competitiveness and increase economic benefit. Seen from current status of financial accounting management of construction enterprises, there exist many problems. Influenced by various factors, the effect of financial accounting management is limited, which prevents the development of construction enterprises. Thus, construction enterprises should pay high attention to financial accounting management and implement corresponding strategies to improve the level of financial accounting management and ensure the maximum benefit of enterprises.

2. INFLUENCING FACTORS IN FINANCIAL ACCOUNTING MANAGEMENT OF CONSTRUCTION ENTERPRISES AND FINANCIAL RISK PREVENTION SYSTEM

2.1. Influencing Factors in Financial Accounting Management of Construction Enterprises

\subsubsection{Objective Social Factors}

The financial accounting management of enterprises is influenced by objective social factors more or less, which prevents the process of financial accounting management activity to some extent [8-10]. Objective social factors mainly include material suppliers, invoices and constructors, etc. Due to huge investment and long payback period, if there is an issue with capital turnover, material expenses will be in arrears badly. In such case, the material suppliers wouldn't issue invoices before the materials are paid, which makes it difficult for the financial department of construction enterprises to keep the books. And it is difficult to distinguish if the invoice issued is true or false. The false invoices have influence on rendering an account. In some construction enterprises, constructors don't get paid on time. Before getting paid, they won't have their name signed, which influences accounting.

\subsubsection{Subjective Factors of Construction Enterprises Themselves}

The subjective factors mainly refer to that construction enterprises lack management ability and well-established system of financial accounting management, that the leadership and management pay little attention to financial accounting management and focus on their own small groups, that there are no clear goals, responsibilities and rights of financial accounting management and the liability system is not implemented, and that the quality of management personnel of financial accounting is not good enough and the enterprises lack professional management personnel.

\subsection{Financial Risk Prevention System}

To avoid risks of business management and operation, the construction enterprises should strengthen risk prevention, preset warning index of financial accounting and establish the financial risk warning model. Among financial warning models, Altman's Z-Score model is most widely applied. The expression of this model is:

$$
\begin{aligned}
& Z=0.012 X_{1}+0.014 X_{2}+0.033 X_{3}+ \\
& 0.006 X_{4}+0.999 X_{5}
\end{aligned}
$$


In the expression,

$\mathrm{X}_{1}=($ current assests - current liabilities $) \div$ total assets;

$\mathrm{X}_{2}=$ retained earnings $\div$ total assets;

$\mathrm{X}_{3}=$ earnings before interest and tax $\div$ total assets;

$\mathrm{X}_{4}=$ market value of shareholder's equity $\div$ total liabilities

$\mathrm{X}_{5}=$ income from the project settlement $\div$ total assets

where market value of shareholder's equity $=$ market value per share $\times$ numbers of tradable shares + net assets per share $\times$ numbers of non-tradable shares (listed companies); market value of shareholder's equity = market value of enterprise assets derived from assets appraisal - total liabilities (nonlisted companies).

The criteria of $\mathrm{Z}$-Score model is: when $\mathrm{Z} \leq 1.8$, there is a greater possibility that financial failure occurs; when $1.8 \leq \mathrm{Z} \leq 2.7$, there is a great possibility that financial failure occurs; when $2.8 \leq Z \leq 2.9$, financial failure might occur; when $\mathrm{Z} \geq 3.0$, there is a small possibility that financial failure occurs.

\section{ANALYSIS OF DEFECTS IN FINANCIAL AC- COUNTING MANAGEMENT OF CONSTRUCTION ENTERPRISES}

\subsection{Lack of Understanding of Financial Accounting Management}

The construction enterprises pay more attention to financial accounting management, but still lack understanding of it, which makes it difficult to carry out the relevant work. Meanwhile, the financial accounting management is not completely implemented and just scratches the surface instead. The management of relevant expenses and materials are not implemented deeply. Thus, there are many omissions in financial accounting management. These omissions are not handled properly and finally greatly influence normal operations of construction enterprises. Incomplete implementation of financial accounting management would also cause omissions and repetitions, which brings unnecessary loss to the enterprises.

\subsection{Lack of Awareness of Risks}

Some management personnel of construction enterprises lack awareness of risks, which makes financial accounting very subjective. Due to lack of standards of financial accounting, the risks of financial accounting management of construction enterprises greatly increase. Furthermore, due to lack of scientific prediction and timely verification on distorted information, it is difficult to carry out the work of financial accounting management and the operational risks of construction enterprises also increase.

\subsection{Lack of Effective Monitoring Mechanism}

Currently some construction enterprises, especially small and medium-sized construction enterprises, don't pay attention to and implement relevant systems of financial accounting management. Even if relevant systems are developed, the corresponding management work has not been implemented strictly. Due to lack of monitoring mechanism, for most construction enterprises, the effect of financial accounting man- agement is not high and management activities are not ensured by certain systems. Meanwhile, in financial accounting management of construction enterprises, there exist serious problems, such as uncontrolled cost, failure to have a budget at the beginning of the year, unclear accounting and unplanned expenses, which cause disorganized financial accounting management and have serious effects on normal operations of enterprises.

\subsection{Lack of High-Qualified Professional Management Personnel}

Currently the management team of financial accounting in construction enterprises is low-qualified, which impedes the implementation of financial accounting management. Due to lack of high-qualified personnel, the enterprise competitiveness is also weakened, which influences the development of construction enterprises to a large extent. Meanwhile, the structure of financial department of construction enterprises is not well set up. There are many management personnel in intermediate links. Unreasonable department structure causes low efficiency of financial accounting activity.

\section{MAJOR STRATEGIES}

\subsection{Construction Enterprises Should Strengthen Under- standing of Financial Accounting Management}

Related personnel in construction enterprises should have a relatively comprehensive understanding of financial accounting management and further ensure financial accounting management proceeds smoothly. Such comprehensive understanding includes continuous updating of management concepts of financial accounting, penetration of financial accounting management in enterprises step by step, introduction of advanced management technology including technologies of computer, Internet and e-commerce, and improvement of management process of financial accounting and its mode of operation, as well as learning from advanced management experience home and abroad to realize informationization, scientification and legislation, taking cost and benefit as the core of financial accounting management, and understanding the role and importance of pre-event management, management in the event and post-event management.

\subsection{Construction Enterprises Should Raise Awareness of Risk Prevention, Establish and Improve the Risk Preven- tion System}

With huge investment, construction enterprises face greater risks in business operation, which have serious effects. Therefore, to avoid risks of business management and operation, the construction enterprises should strengthen risk prevention, preset warning index of financial accounting, take predictive analysis of risks and decide the value of warning standards. There is great difference in capital operation and financial structure in different China's construction enterprises. So construction enterprises should combine their own actual conditions, including business scale, business state and strength, to establish corresponding risk prevention system, improve the management of accounts receivable and strengthen periodic verification, optimize the debt-to-asset ratio and then further prevent financial risks effectively. 
4.3. Construction Enterprises Should Strengthen Establishment and Improvement of Internal Monitoring System

Establishing and improving internal monitoring system is to enhance the efficiency and level of financial accounting management and ensure survival and development of enterprises. The establishment and improvement of internal monitoring system include setting up independent auditing department to form vertical auditing management, establishing and improving correction mechanism and internal control report and accepting the supervision from other departments except financial department, and fully utilizing advanced technologies of computer and Internet to implement supervision on financial accounting management.

4.4. Construction Enterprises Should Strengthen Establishment of the Management Team of Financial Accounting

To ensure accuracy, high efficiency and quickness of information of financial accounting management, construction enterprises need pay attention to establishment of the management team of financial accounting, continuously improve the team quality, simplify and optimize financial management department. To the management personnel of financial accounting, besides having professional skills, they should also have strong market foresight and insight and then according to the needs of enterprises, develop financial plans suitable for the market to promote development of enterprises and ensure the benefit of enterprises.

\section{ESTABLISHMENT OF FINANCIAL RISK PRE- VENTION}

For construction enterprises, the financial risks are mainly caused by external environmental factors and internal environmental factors. External environmental factors
Table 1. External financial warning index.

\begin{tabular}{|c|c|}
\hline External Warning Index & Nature \\
\hline \hline Related national policies & Qualitative index \\
\hline Intensity of industrial competition & Qualitative index \\
\hline Intensity of market competition & Qualitative index \\
\hline $\begin{array}{c}\text { Changes of taxes, exchange rate and interest rate } \\
\text { Volume of investment in fixed assets }\end{array}$ & $\begin{array}{l}\text { Qualitative index } \\
\text { Qualitative index }\end{array}$ \\
\hline
\end{tabular}

mainly include natural environmental factors (such as earthquake, landslide, high temperature and severe cold influencing safety in construction, construction process and quality), social economic factors (such as inflation caused by economic policies and financial risks caused by changes of price, loan policy, interest rate and exchange rate), political and legal factors and so on. These factors bring risks to those construction enterprises with long period of operating cycle. Internal environmental factors include construction quality, time limit, safety, construction machinery and quality of management personnel, etc. Table 1 shows the external financial warning index, Table 2 shows the internal financial warning index, Table 3 shows the profit warning index, and Table 4 shows the operation warning index.

The construction enterprises usually adopt traditional and isolated management method to prevent risks, which is only limited to control and management of financial risks and fails to achieve effective pre-event prevention, prevention in the event and post-event prevention of risks. It is mainly because construction enterprises could not classify financial risks correctly and clearly. And financial risks keep changing. Therefore, to prevent financial risks, the enterprises can use the financial risk monitoring index and build the financial risk warning model and so on.

Table 2. Internal financial warning index.

\begin{tabular}{|c|c|c|c|}
\hline & Internal Warning Index & Standard Reasonable Range & Nature \\
\hline \multirow{2}{*}{ Short-term liquidity } & Current ratio & Business features and industry level & 2 in general \\
\hline & Quick ratio & Business features and industry level & 1 in general \\
\hline \multirow{2}{*}{ Long-term liquidity } & Debt-to-assets ratio & Business features and industry level & Big industry level gap \\
\hline & Times interest earned & Business features and industry level & $<1$ or close to 1 \\
\hline
\end{tabular}

Table 3. Profit warning index.

\begin{tabular}{|c|c|c|}
\hline Warning Index & Standard Reasonable Range & Nature \\
\hline \hline Profit rate of major businesses & Industry features. The greater, the better. & \\
\cline { 1 - 2 } Return on net assets & Industry features. The greater, the better. & \multirow{2}{*}{ Close to 0, or decline greatly } \\
\cline { 1 - 2 } Return on total assets & Industry features. The greater, the better. & \\
\cline { 1 - 2 } Earnings per share & Industry features. The greater, the better. & Increase greatly \\
\hline Ratio of profits to cost & Industry features. The greater, the better. & \multirow{2}{*}{} \\
\hline
\end{tabular}


Table 4. Operation warning index.

\begin{tabular}{|c|c|c|}
\hline Warning Index & Standard Reasonable Range & Nature \\
\hline \hline Turnover rate of accounts receivable & \multirow{2}{*}{$\begin{array}{c}\text { Andustry features, contrastive analysis and trend } \\
\text { analysis of credit policy of the enterprise }\end{array}$} & \multirow{2}{*}{ Abnormalities and big industry level gap } \\
\cline { 1 - 1 } Turnover rate of fixed assets & Industry features and business scale & \\
\cline { 1 - 1 } Turnover rate of current assets & & \\
\cline { 1 - 1 } Operating-asset-to-total-asset ratio & &
\end{tabular}

\subsection{Financial Risk Monitoring Index}

The financial risk monitoring index mainly includes debtto-assets ratio, debt coverage ratio, quick ratio, current ratio and return on investment. Analyze and forecast these indexes periodically and combine the operation state to determine the warning range. When all indexes are within the warning range, it indicates that the business operation is in a relatively safe condition. When some indexes are beyond the warning range, it indicates that the enterprise faces financial risks and need take corresponding measures to deal with financial risks, including bidding the project carefully and strengthening debt collection, and then have the indexes maintained in normal range.

\subsection{Establishment of Financial Risk Warning Model}

The construction enterprises can utilize above formula and combine data from the statistical software and consecutive accounting periods to establish the financial risk warning model. This model has wide range of application. It can be used to forecast the financial situation of the enterprise itself, and also to analyze the financial situation of the competitors, customers and suppliers. In the application of this model, the enterprise should pay attention to these issues: 1 . this model could not be used to compare the enterprises with different scale and in different industries; 2 . this model does not take the cash flow index into consideration and thus could not reflect the real financial quality; 3 . this model is applicable to short-term financial risk prediction in 1 2 years and if it is used for a long time, its accuracy will reduce.

Take some construction enterprise for example, put the data on December 31, 2010 into the formula and get the results (calculated in ten-thousand Yuan): $\mathrm{X}_{1}=4595 /$ $15959=0.3104, X_{2}=3173 / 15959=0.2, X_{3}=970 / 15959=0.0607$, $\mathrm{X}_{4}=15000 / 15919=0.942, \mathrm{X}_{5}=48000 / 15959=3.0077$ and then $\mathrm{Z}=3.11242>3.0$. Therefore, the financial situation of this enterprise is in good condition and there is a very small possibility to have financial risks.

\subsection{Financial Warning Mechanism Combining Report Analysis and Index Analysis}

The method of report analysis mainly includes the ratio method and comparison method. The specific indexes include debt paying ability (such as current ratio, quick ratio, debt-to-assets ratio and equity ratio), turnover ability (such as turnover rates of accounts receivable, current assets, inventory, fixed assets and assets) and profitability (such as net profit rate of assets, return on net assets and net profit rate of sales). When the current ratio (current assets/current liabili- ties) is around 2, it indicates that the enterprise has plenty of cash. When the quick ratio (quick assets/current liabilities) is 1 , it indicates that the financial situation of the enterprise is in the margin of safety (ideal assets and liabilities). The smaller the debt-to-assets ratio (total liabilities/total assets), the stronger the debt paying ability; the debt-to-assets ratio is usually around $50 \%$; when this ratio is over $70 \%$, the enterprise is at risk of bankruptcy. For the equity ratio (total liabilities/stockholder's equity), the higher the stockholder's equity, the smaller the business risks. The higher turnover rate of accounts receivable indicates the quick debt collection and shorter aging; the more the liquid assets, the stronger the short-term debt paying ability.

\section{CONCLUSION AND SUGGESTION}

There are still certain issues in financial accounting management of construction enterprises. Therefore, on the basis of paying high attention to and fully understanding financial accounting management, the construction enterprises should positively take measures to deal with the defects in financial accounting management. Combine the actual business conditions, make deep analysis of various defects, take scientific and effective strategies and further improve the level and efficiency of financial accounting management. This paper establishes the financial risk warning system against the weak risk awareness, which can support the financial accounting management of construction enterprises to some extent. Certainly, there are more other problems in financial accounting management. Therefore, deep analysis of other strategies should still be conducted.

\section{CONFLICT OF INTEREST}

The author confirms that this article content has no conflict of interest.

\section{ACKNOWLEDGEMENTS}

Declared none.

\section{REFERENCES}

[1] A. E. Akgün, I. Huseyin, S. Z. Imamoglu, K. Halit, K. Ipek, "The mediator role of learning capability and business innovativeness between total quality management and financial performance," International Journal of Production Research, vol. 52, no. 3, pp. 888901, 2014.

[2] R. McMahon, and S. Holmes, "Small business financial management practices in North America: a literature review," Journal of Small Business Management, vol. 29, no. 2, p. 19, 1991.

[3] C. U. Pyon, J. Y. Woo, and S. C. Park, "Service improvement by business process management using customer complaints in finan- 
cial service industry," Expert Systems with Applications, vol. 38, no. 4, pp. 3267-3279, 2011.

[4] C.L. Lee, C.T. Ho, and Y.L. Chiu, "The impact of knowledge management enablers on non-financial performance in small and medium enterprises," International Journal of Technology Management, vol. 43, no. 1-3, pp. 266-283, 2008.

[5] T. Chen, "Research on enterprise accounting system based on business flow, "Biotechnology: An Indian Journal, vol. 10, no. 9, pp. 4173-4180, 2014.

[6] J. de Jong, "Modeling financial statement preparation of a SME enterprise by an accountancy firm, " Lecture Notes in Business Information Processing, vol. 174, pp. 91-104, 2014.
[7] L.V. Vykydanets, "Conceptual approach to development of financial strategy of enterprise's capital formation, " Naukovyi Visnyk Natsionalnoho Hirnychoho Universytetu, vol. 2, pp. 110-115, 2013.

[8] M. Renáta, "Company information systems used in decisionmaking processes of financial managers, " WSEAS Transactions on Systems, vol. 8, no. 4, pp. 532-542, 2009.

[9] B. C. Peacock, "Watershed-scale prioritization of habitat restoration sites for non-point source pollution management, " Ecological Engineering, vol. 42, pp. 174-182, 2012.

[10] L. D'Andrea, A. Declich, and F. Feudo, "Hidden societal implications of materials. Updating the awareness on what is at stake, " Materiaux et Techniques, vol. 102, no. 5, 2014.

(C) Linfang Hou; Licensee Bentham Open.

This is an open access article licensed under the terms of the (https://creativecommons.org/licenses/by/4.0/legalcode), which permits unrestricted, noncommercial use, distribution and reproduction in any medium, provided the work is properly cited. 